
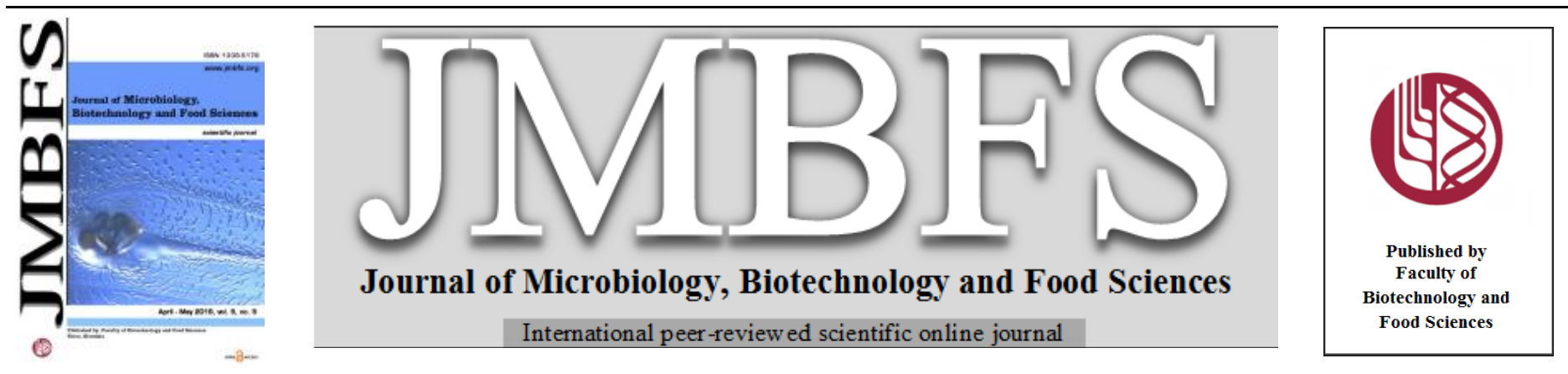

\title{
CHARACTERIZATION OF DIARRHEAGENIC ESCHERICHIA COLI ISOLATED FROM RAW BEEF, MUTTON, AND INTESTINES SOLD IN OUAGADOUGOU, BURKINA FASO
}

\author{
Hadiza Bawa Ibrahim ${ }^{* 1}$, Gertrude Bsadjo Tchamba ${ }^{1}$, Touwendsida Serge Bagré ${ }^{1}$, Soutongnooma Caroline Bouda ${ }^{1}$, Alio Mahamadou \\ Fody ${ }^{1,2}$, Assèta Kagambèga ${ }^{1,3}$, Isidore Juste O.Bonkoungou, ${ }^{1,4}$, Fidèle Tiendrebéogo ${ }^{1,5}$, Cheikna Zongo ${ }^{1}$, Aly Savadogo ${ }^{1}$, Alfred S. \\ Traorél $^{l}$ and Nicolas Barrol
}

\begin{abstract}
Address(es): et Technologies. Université de Ouagadougou, 03 B.P 7021 Ouagadougou 03, Burkina Faso.

${ }^{2}$ Laboratoire de Biologie, Hôpital National de Niamey (HNN), BP 238 Niamey, Niger.

${ }^{3}$ Institut Des Sciences, 01 BP 1757 Ouagadougou 01, Burkina Faso.

${ }^{4}$ Laboratoire National de Santé Publique (LNSP), 09 BP 24 Ouagadougou, Burkina Faso.

${ }^{5}$ Institut de l'Environnement et de Recherches Agricoles (INERA) 04 BP 7192 Ouagadougou 04, Burkina Faso.
\end{abstract}

${ }^{1}$ Laboratoire de Biologie Moléculaire d'Epidémiologie et de Surveillance des agents Transmissibles par les Aliments (LaBESTA). Centre de Recherche en Sciences Biologiques, Alimentaires et Nutritionnelles (CRSBAN). Département de Biochimie-Microbiologie. UFR en Sciences de la vie et de la terre. Ecole Doctorale Sciences

*Corresponding author: hadizabawa@yahoo.fr

doi: $10.15414 / j m b f s .2016 .5 .5 .470-474$

ARTICLE INFO

Received 6.11.2015

Revised 11. 12. 2015

Accepted 5. 1.2016

Published 1. 4. 2016

Regular article

open $\partial_{\text {ACCESS }}$

\begin{abstract}
Diarrheagenic Escherichia coli are zoonotic bacteria commonly present in animal gut. The aim of our study was to determine the prevalence of diarrheagenic $E$. coli isolated from raw meats and intestines in open markets of Ouagadougou, Burkina Faso. A total of 450 samples were collected from beef, mutton, beef intestine and sheep intestine, in respective number 175, 175, 50 and 50. Diarrheagenic E. coli were isolated by using standard microbiological methods and then Multiplex Polymerase Chain Reaction was used for characterization. Among the pathotypes, enteropathogenic E. coli was identified by serotypage (slide agglutination). A 30\% (135/450) were E. coli. 30\% (40/135) of E. coli strains provided the virulence genes. 14\% of Shiga toxin producing Escherichia coli, $13 \%$ of shiga toxin producing Escherichia coli-enterotoxinogenic Escherichia coli, $1 \%$ of enteroaggregative Escherichia coli, $2 \%$ of enteroinvasive Escherichia coli and 1\% of enterotoxinogenic Escherichia coli. 41\% (55/135) were enteropathogenic Escherichia coli belong to serotypes: (5\%), O119 (3\%), O127 (16\%), O125 (9\%), O126 (18\%), O128 (5\%), O114 (5\%), O124 (5\%), O142 (7\%). This study show contamination of slaughter animal with diarrheagenic E. coli pathotypes in Burkina Faso. Precaution can take of mutation breeding level.
\end{abstract}

Keywords: Beef, Mutton, Raw intestines, Diarrheagenic E. coli, Burkina Faso

\section{INTRODUCTION}

Meat and meat products, second food outbreak are associated several cases of collective foodborne diseases worldwide (EFSA, 2012; OMS, 2015). Meat, being it a nutrient-rich substrate, can support the growth of a wide range of microorganisms, which also include Escherichia coli. The latter has received much attention as a potential public health threat due to the morbidity and mortality rates associated with outbreak and sporadic cases of human illness (Paton and Paton, 1998). However, people who have died from diarrheal diseases were estimated to 2 million cases (OMS, 2015), including a large proportion cases from the consumption of contaminated food. In Burkina Faso, many studies showed that diarrheal diseases are caused by E. coli (Bonkoungou et al., 2012; Timbiné et al., 2013; Dembélé et al., 2015). Various diseases have been reported due to ingestion of food contaminated with pathogenic Escherichia coli (Fadi et al., 2012; Kagambèga et al., 2012; Croxen et al., 2013). There are several pathovars of Escherichia coli described as clinical generate indication. Pathogenic strains are divided into intraintestinal E. coli pathogens causing diarrhea and extraintestinal $E$. coli causing a variety of infection in both humans and animals (Jafari et al., 2012). Diarrheagenic E. coli possess virulence factors which are responsible for their pathogenicity. They include enteropathogenic $E$. coli (EPEC), enteroaggregative E. coli (EAEC), enterotoxigenic E. coli (ETEC), enteroinvasive E. coli (EIEC), enterohaemorrhagic E. coli (EHEC), and diffusely adherent E. coli (DAEC) (Nataro and Kaper, 1998; Igbeneghu and Lamikanra, 2014; Saeed et al., 2015). Among them enteropathogenic Escherichia coli (EPEC) is a major cause of infantile diarrhea among children under five years in developing countries (Jafari $\boldsymbol{e t}$ al., 2012; Kotloff $\boldsymbol{e t}$ al., 2013; Croxen et al., 2013; Dembélé et al., 2015).
In Burkina Faso there are a few data concerning the prevalence of diarrheagenic $E$. coli in food stuffs. Therefore, the objective of our study was to determine diarrheagenic E. coli pathotypes from meat and intestines samples sold at some open markets in Ouagadougou and to identify the prevalent serogroups of EPEC.

\section{MATERIALS AND METHODS}

Study design and sampling

Sampling of raw meats and intestines of beef and sheep were carried out in twenty-five (25) open markets of Ouagadougou. Overall 450 samples: 175 samples of beef, 175 samples of mutton, 50 samples of beef intestine and 50 samples of sheep intestine were collected from each animal after slaughtering. Approximatively 400g were collected aseptically from October 2011 to October 2012. The samples were placed in sterile plastic bags and transported to the laboratory and kept at $4^{\circ} \mathrm{C}$ until microbial examination within $2 \mathrm{~h}$.

Isolation and identification of $E$. coli

\section{Samples processing}

The ISO 4832, 1991 lightly modified were used for the isolation of E. coli. Twenty five (25) g of each sample was transferred in to $225 \mathrm{ml}$ of buffered peptone water (Liofilchem, Italy) and was homogenized in a stomacher LAB BLENDER 400 (Sewar, England). The suspension of meat was incubated at $37^{\circ} \mathrm{C}$. 


\section{Isolation of $E$. coli}

After $24 \mathrm{~h}$ of incubation two (2) loopful of pre-enrichment broth were streaked onto Eosin Methylene Blue (EMB) agar (Liofilchem, Italy) and Violet Red Bile Lactose (VRBL) agar (Liofilchem, Italy). The plates were incubated at $44{ }^{\circ} \mathrm{C}$ for 18-24 hours. Suspect E. coli colonies were appeared metallic green on EMB agar and as small colonies purple with a purple cloud on VRBL agar.

\section{Identification of $\boldsymbol{E}$. coli}

The suspect colonies were selected and streaked onto Mueller Hinton agar (Liofilchem, Italy). Confirmation was carried out by biochemical microbiology method based on negative urease (Bio-Rad, French), negative citrate (Liofilchem, Italy), positive indole (Bio-Rad, France), positive lactose (Lioflchem, Italy) and positive orthonitrophenyl- $\beta$-D-galactopyranoside (ONPG) (BioMerieux, France). The E. coli strains isolated were confirmed by API 20E (BioMérieux, France) system and API 20E interpretation was done by API 20E catalogue.

\section{Multiplex polymerase chain reaction (16 plex PCR)}

The 16-plex PCR was used to detect simultaneously 16 genes of 5 main pathogroups of E. coli (STEC, STEC-ETEC, EAEC, EIEC and ETEC) as describe by Antikainen et al., (2009). The genes investigated and primers used are described in (Tab 1). DNA extraction was performed using heating method (Moyo et al., 2007). A loopful of bacterial growth of Mueller Hinton agar plate was suspended in $1.5 \mathrm{ml}$ of distilled sterile water. The mixture was boiled for 10 min and centrifuged for $10 \mathrm{~min}$ at $11337 \mathrm{rpm}$. The supernatant was collected and used in the PCR reactions. One (1) $\mu 1$ of supernatant was added to $19 \mu 1$ reaction mixture containing $1 \mathrm{U}$ of Taq DNA polymerase (AccuPower, korea), deoxyribonucleic triphosphate $(250 \mathrm{mM})$, Tris $\mathrm{HCl}(\mathrm{pH} 9,0)(10 \mathrm{mM}), \mathrm{KCl}(30$ $\mathrm{mM}), \mathrm{MgCl}_{2}(1.5 \mathrm{mM})$, and PCR primers (escV, bfpB, stx1, stx2, LT, STIa, STI, invE, astA, aggR, pic, uidA, hly, , eaeA, ipaH ent) $(100 \mu \mathrm{M})$ (STEC, STECETEC, EAEC, EIEC, ETEC). Thermocycling conditions were as follows: $30 \mathrm{~s}$ at $98^{\circ} \mathrm{C}$, followed by 35 amplification cycles of $98^{\circ} \mathrm{C}$ for $30 \mathrm{~s}, 62.5^{\circ} \mathrm{C}$ for $60 \mathrm{~s}$ and $72^{\circ} \mathrm{C}$ for $90 \mathrm{~s}$ with a final extension of $72^{\circ} \mathrm{C}$ for $10 \mathrm{~min}$ on a thermal cycler (Perkins Helmer Cetus, USA). Following PCR, the reaction products were separated to electrophoresis in ( $2 \%$ weight/volume) agarose gel, stained with ethidium bromide solution (Prolabo, France) and visualized under UV light (Applex, France). Reference strains (FE 102301 (stx2, eae, escV, ent EHEC-hly), FE 95562 (stx1, EHEC-hly, estla, astA, uidA), IHE 56822 (aggR, pic, astA, uidA), RHE 6647 (invE, ipaH, uidA), FE 94725 (elt, astA) and IHE 50246 (uidA)) were used in each PCR run

Table 1 Oligonucleotides primers used for Multiplex PCR reaction

\begin{tabular}{|c|c|c|c|c|c|}
\hline Pathotype & $\begin{array}{l}\text { Target } \\
\text { gene }\end{array}$ & Primer Sequence (5'to3') & $\begin{array}{c}\text { PCR } \\
\text { product } \\
\text { size (bp) }\end{array}$ & $\begin{array}{l}\text { Concentration } \\
(\mu \mathrm{M})\end{array}$ & Reference \\
\hline \multirow{10}{*}{ STEC } & \multirow{2}{*}{ Stx 2} & MP3-stx2A F:GTTTTGACCATCTTCGTCTGATTATTGAG & 324 & 0.4 & Müller et al., 2007 \\
\hline & & MP3-stx2A-R:AGCGTAAGGCTTCTGCTGTGAC & & 0.4 & \\
\hline & \multirow{2}{*}{$e a e A$} & eae-F:TCAATGCAGTTCCGTTATCAGTT & 482 & 0.1 & Müller et al., 2007 \\
\hline & & eae-R:GTAAAGTCCGTTACCCCAACCTG & & 0.1 & \\
\hline & \multirow{2}{*}{$e s c V$} & MP3-escV-F:ATTCTGGCTCTCTTCTTCTTTATGGCTG & 544 & 0.4 & Müller et al., 2007 \\
\hline & & MP3-escV-R:CGTCCCCTTTTACAAACTTCATCGC & & 0.4 & \\
\hline & \multirow{2}{*}{ ent } & ent-F:TGGGCTAAAAGAAGACACACTG & 629 & 0.4 & Müller et al., 2007 \\
\hline & & ent-R:CAAGCATCCTGATTATCTCACC & & 0.4 & \\
\hline & \multirow{2}{*}{ Stx 1} & MP4-stx1A-F:CGATGTTACGGTTTGTTACTGTGACAGC & 244 & 0.2 & Müller et al., 2007 \\
\hline & & MP4-stx1A-R:AATGCCACGCTTCCCAGAATTG & & 0.2 & \\
\hline \multirow{4}{*}{ EAEC } & \multirow{2}{*}{$\operatorname{aggR}$} & MP2-aggR-F:ACGCAGAGTTGCCTGATAAAG & 400 & 0.2 & Müller et al., 2007 \\
\hline & & MP2-aggR-R:AATACAGAATCGTCAGCATCAGC & & 0.2 & \\
\hline & \multirow{2}{*}{ pic } & MP2-pic-F:AGCCGTTTCCGCAGAAGCC & 1,111 & 0.2 & Müller et al., 2007 \\
\hline & & MP2-pic-R:AAATGTCAGTGAACCGACGATTGG & & 0.2 & \\
\hline \multirow{4}{*}{ EIEC } & \multirow[t]{2}{*}{$i n v E$} & MP2-invE-F:CGATAGATGGCGAGAAATTATATCCCG & 766 & 0.2 & Müller et al., 2007 \\
\hline & & MP2-invE-R:CGATCAAGAATCCCTAACAGAAGAATCAC & & 0.2 & \\
\hline & \multirow{2}{*}{ ipaH } & ipaH-F: GAAAACCCTCCTGGTCCATCAGG & 437 & 0.1 & Vidal et al., 2005 \\
\hline & & ipaH-R:GCCGGTCAGCCACCCTCTGAGAGTAC & & 0.1 & \\
\hline \multirow{4}{*}{ ETEC } & \multirow{2}{*}{ elt } & MP2-LT-F:GAACAGGAGGTTTCTGCGTTAGGTG & 655 & 0.1 & Müller et al., 2007 \\
\hline & & MP2-LT-R:CTTTCAATGGCTTTTTTTTGGGAGTC & & 0.1 & \\
\hline & \multirow{2}{*}{ astA } & MP2-astA-F:TGCCATCAACACAGTATATCCG & 102 & 0.4 & Müller et al., 2007 \\
\hline & & MP2-astA-R:ACGGCTTTGTAGTCCTTCCAT & & 0.4 & \\
\hline \multirow{2}{*}{ E.coli } & \multirow{2}{*}{ uidA } & MP2-uidA-F:ATGCCAGTCCAGCGTTTTTGC & 1,487 & 0.2 & Vidal et al., 2005 \\
\hline & & MP2-uidA-R:AAAGTGTGGGTCAATAATCAGGAAGTG & & 0.2 & \\
\hline
\end{tabular}

Legend. $\mathrm{STEC}=E$. coli producing shiga toxine, ETEC $=E$. coli enterotoxinogenic, EAEC $=E$. coli enteroaggregative, EIEC $=E$. coli enteroinvasive, $\mathrm{PCR}=$ polymerase chain reaction, $\mu \mathrm{M}=$ micromolaire, $\mathrm{pb}=$ paire de base.

\section{Serotyping}

EPEC serogroups were identified by slide agglutination test using nonavalent, trivalent and monovalent antisera (Bio-Rad, France) according to the method described by Neter et al., (1955) lightly modified. The first test witness was carried out with physiological solution to check if the strain was not autoagglutinable. If not, trivalent I $(\mathrm{O} 111+\mathrm{O} 55+\mathrm{O} 26)$, II $(\mathrm{O} 86+\mathrm{O} 119+$ O127), III (O125 + O126 + O128) and trivalent IV (O114 + O124 + O142) antisera were used. Finally, monovalent antisera were used according to the manufacturers. Only strong agglutination occurring within 1 min was considered to be positive reaction.

\section{RESULTS AND DISCUSSION}

\section{Total prevalence of $E$. coli}

Foodborne diseases are of utmost concern for public health due to their direct impact on consumer. Our study showed that 30\% (135/450) among 450 samples analyzed were isolated E. coli (tab 2). The highest prevalence was isolated from beef with $33 \%(57 / 175)$, followed by mutton $26 \%(46 / 175)$. The same prevalence $32 \%(16 / 50)$ of E. coli was isolated from beef and sheep intestines. This high prevalence is sometimes responsible of the non-conformity of meat processing environment such as reported by many authors (Barro $\boldsymbol{e t}$ al., 2007; Ilboudo $\boldsymbol{e t}$ al., 2010; Kagambèga et al., 2012). 
Table 2 Prevalence of $E$. coli strains on meats and intestines samples Samples $(\mathrm{n}=450) \quad$ Number of isolates

\begin{tabular}{lc}
\hline Beef $(\mathrm{n}=175)$ & $57(33 \%)$ \\
Beef intestine $(\mathrm{n}=50)$ & $16(32 \%)$ \\
Mutton $(\mathrm{n}=175)$ & $46(26 \%)$ \\
Sheep intestine $(\mathrm{n}=50)$ & $16(32 \%)$ \\
\hline Total prevalence & $135(30 \%)$ \\
\hline
\end{tabular}

Legend: $\mathrm{n}=$ number of sample, $\%=$ percentage.

Table 3 Prevalence of $E$. coli carrying different virulence genes

\begin{tabular}{|c|c|c|c|c|c|c|c|c|c|c|c|c|c|c|c|c|}
\hline Virulence genes & & & & & & & & & & & & & & & & \\
\hline Pathotypes & stx $x_{1}$ & stx $x_{2}$ & eae & escv & ent & EHEC-hly & $b f p b$ & aggr & pic & inve & ipah & elt & estla & estb & asta & uida \\
\hline $\begin{array}{l}\text { Beef }(n=33) \\
\text { STEC }\end{array}$ & - & 2 & 3 & 4 & 1 & - & - & - & - & $\begin{array}{ll}- & \text { r }\end{array}$ & - & - & 1 & - & $\begin{array}{lll}- & \text { r }\end{array}$ & - \\
\hline STEC-ETEC & 7 & - & 1 & - & - & 1 & - & - & - & - & - & - & 6 & - & 6 & 7 \\
\hline EAEC & - & - & - & - & - & - & - & - & 1 & - & - & - & - & - & - & - \\
\hline EIEC & & & & & & & & & & 1 & 1 & - & - & - & - & 1 \\
\hline ETEC & & & & & & & & & & & & 1 & - & - & 1 & 1 \\
\hline
\end{tabular}

\begin{tabular}{|c|c|c|c|c|c|c|c|c|c|c|c|c|c|c|c|c|}
\hline \multicolumn{17}{|c|}{ Beef intestine $(n=7)$} \\
\hline STEC & - & - & - & - & - & - & - & - & - & - & - & - & - & - & - & - \\
\hline STEC-ETEC & 2 & - & - & - & - & - & - & - & - & - & - & - & 1 & - & - & 2 \\
\hline EAEC & - & - & - & - & - & - & - & - & - & - & - & - & - & - & - & - \\
\hline EIEC & - & - & - & - & - & - & - & - & - & - & - & - & - & - & - & - \\
\hline ETEC & - & - & - & - & - & - & - & - & - & - & - & - & - & - & - & - \\
\hline
\end{tabular}

Mutton (n=29)

STEC

STEC-ETEC

EAEC

EIEC

ETEC

Sheep intestine $(\mathrm{n}=11)$

STEC

STEC-ETEC

EAEC

EIEC

ETEC

Legend: $\mathrm{STEC}=E$. coli producing shiga toxine, $\mathrm{ETEC}=E$. coli enterotoxinogen, $\mathrm{EAEC}=E$. coli enteroaggregative, EIEC $=E$. coli enteroinvasive, $-=$ no prevalence, $\mathrm{n}=$ number of gene

Otherwise, five (5) mainly pathotypes of $E$. coli were detected by 16 plex PCR The stx gene is the most detected with a high prevalence of STEC. In fact, STEC is responsible for diseases in humans and animals whose clinical spectrum includes hemorrhagic colitis (HC), hemolytic uremic syndrome (HUS) and thrombotic thrombocytopenic purpura (TTP) (Nataro and Kaper, 1998) Globally, the prevalence of STEC is higher in meat than other foods in Burkina Faso and other countries (Kagambèga et al., 2012; Rahimi and Nayebpour, 2012; Isibor et al., 2013; Mori et al., 2014). However, the low prevalence of ETEC, EAEC and EIEC pathotypes were recorded respectively in mutton and beef only. These results are similar to studies conducted in Senegal, Burkina Faso, Morocco and Iran (Gassama-Sow et al., 2004; Kagambèga et al., 2012; Fadi et al., 2012; Jafari et al., 2012; Sarker et al., 2013). The most important mode of transmission diarrheagenic E. coli is the contaminated meat. Person to person transmission is possible, but not frequent because there is the high

\section{Prevalence of diarrheagenic $E$. coli pathotypes}

From 135 E. coli strains, 59\% (80/135) were identified by 16 plex PCR among others $30 \%(40 / 135) E$. coli strains provided the virulence genes. Five (5) E. coli pathotypes were identified: STEC 14\% (18/135), STEC-ETEC 13\% (17/135), EAEC 1\% (1/135), EIEC 2\% (3/135) and ETEC 1\% (1/135) in the meat samples. The higher prevalence was observed in STEC and STEC-ETEC. The genes uidA were identified only in $30 \%(40 / 135)$ E. coli strains; however, they were considered like non diarrheagenic E. coli (tab 3). 
Table 4 Prevalence of enteropathogenic E. coli in the beef, sheep and intestines raw meats

$\begin{array}{llll}\text { Trivalent I } & \text { Trivalent II } & \text { Trivalent III } & \text { Trivalent IV }\end{array}$

Samples

\section{1}

O119

0127

0125

0126

0128

$\mathrm{O} 114$

0124

0142

Total EPEC

\begin{tabular}{|c|c|c|c|c|c|c|c|c|c|c|c|c|c|}
\hline Beef & $1(2 \%)$ & $1(2 \%)$ & $3(5 \%)$ & $1(2 \%)$ & $1(2 \%)$ & $4(7 \%)$ & $2(4 \%)$ & $5(9 \%)$ & $2(4 \%)$ & $1(2 \%)$ & $1(2 \%)$ & $2(4 \%)$ & $24(44 \%)$ \\
\hline Beef intestine & $1(2 \%)$ & - & - & - & - & - & $1(2 \%)$ & $2(4 \%)$ & - & $2(4 \%)$ & $2(4 \%)$ & $1(2 \%)$ & $9(16 \%)$ \\
\hline Sheep intestine & - & $1(2 \%)$ & $1(2 \%)$ & - & - & - & - & $1(2 \%)$ & $1(2 \%)$ & - & - & $1(2 \%)$ & $5(9 \%)$ \\
\hline
\end{tabular}

Legend: -= none, EPEC = enteropatogenic $E$. coli, \% = percentage

EPEC identified in raw meats and intestines from the open market shown different proportions in this study. This pathogroup was isolated in several similar studies (Kagambèga et al., 2012; Fadi et al., 2012; Mori et al., 2014) from raw meats. The prevalence of EPEC is highest and are most isolated from human than foods and animal, but the transmission of this pathogen to human occurs through various mechanism: consumption of contaminated ground meat and drinking unpasteurized milk (Kagambèga et al., 2012; Isibor et al., 2013; Bagré et al., 2014); consumption contaminated water, vegetables and juice (Isibor et al., 2013; Bsadjo Tchamba et al., 2014). The slaughtering and the transformation are the step of production generally considered as trunks of risk in frame of the prevention of EPEC that contaminated the meat (Cohen and Karib, 2006). According to several authors, EPEC constitutes the first cause of diarrhea in infant and child less than five years old in Burkina Faso (Bonkoungou et al., 2012; Dembélé et al., 2015), and other authors Croxen et al., (2013); Igbeneghu and Lamikanra, (2014); Saeed et al., (2015).

A high proportion of STEC, STEC-ETEC and EPEC strains were obtained in this study from beef and mutton raw meats and intestines considering these animals as potential zoonotic reservoir of STEC, STEC-ETEC and EPEC. Prevent cross contamination in food preparation areas by thoroughly washing hands, counters, cutting boards, and utensils after they touch raw meat. Knowledge of transmission routes and vehicles allows consumers to be educated on reducing risky behavior that can decrease their risk for infection.

\section{CONCLUSION}

The current study confirms the presence of DEC strains in beef and mutton. Also cross contamination by contact with areas of selling previously contaminated with raw meat and contact with the raw meat itself can lead a factor risk for consumers. The preventives measures must be integrated in the slaughterhouse and in the nice practices of hygiene of production. The prevalence of virulent $E$. coli indicated risk exposure of the population.

Acknowledgements: The authors are grateful to the French Government for their financial support, and all meat sellers to their cooperation for samples collection.

\section{REFERENCES}

Antikainen, J., Tarkka, E., Haukka, K., Siitonen, A., Vaara, M., Kirveskari, J. (2009). New 16 plex PCR method for rapid detection of diarrheagenic Escherichia coli directly from stool samples. European Journal of Clinical Microbiology and Infectious Diseases. 28, 899-908.

Bagré, TS., Kagambèga, A., Bawa, I. H., Bsadjo Tchamba, G., Dembélé, R., Zongo, C., Savadogo, A., Aggad, H., Traoré, AS., Barro, N. (2014). Antibiotic susceptibility of Escherichia coli and Salmonella strains isolated from raw and curds milk consumed in Ouagadougou and Ziniaré, Burkina Faso. African Journal of Microbiology Research. 8, 1012-1016.

Barro, N., Gamene, A. A., Itsiembou, Y., Sawadogo, A., Nikiema, A. P., Ouattara, C. A. T., De Souza, C. A, Traoré, A.S. (2007). Street vended foods improvement: Contamination Mechanisms and Application of Food Safety Objective Strategy. Critical Review: Pakistan Journal of Nutrition. 6, 1-10.

Bonkoungou, I. J. O., Lienemann, T., Martikainen, O., Dembele, R., Sanou, I., Traore, A. S., Siitonen, A., Barro, N., Haukka, K. (2012). Diarrhoeagenic Escherichia coli detected by 16 plex PCR in children with and without diarrhea in Burkina Faso. Clinical Microbiology and Infection. 18, 901-906. http://dx.doi.org/10.1111/j.1469-0691.2011.03675.x

Bsadjo Tchamba, G., Bawa, I. H., Nzouankeu, A., Bagré, T. S., Dembélé, R., Bonkoungou, I. J. O., Zongo, C., Savadogo, A., Traoré, A. S., Barro, N. (2014) Occurrence and antimicrobial susceptibility of Escherichia coli and Salmonella spp. isolated from "zoom-koom" beverage and ice in Ouagadougou, Burkina Faso. African Journal of Microbiology Research. 8, 3243-3249.

Cohen, N., Karib, H. (2006). Risque hygiénique lié à la présence des Escherichia coli dans les viandes et les produits carnés: Un réel problème de santé publique? Les Technologies de Laboratoire - $N^{\circ} 1$. Correspondance: Email adresse:nozha.cohen@pasteur.ma, 4-9.

Croxen, M. A., Law, R. J., Scholz, R., Keeney, K. M., Wlodarska, M., Finlay, B. B. (2013). Recent Advances in Understanding Enteric Pathogenic Escherichia coli. Clinical Microbiology Reviews. 26, 822-880.

Dembélé, R., Bonkoungou, I. J. O., Konaté, A., Bsadjo-Tchamba, G., Bawa, I. H., Bako, E., Bagré, T. S., Kagambèga, A., Zongo, C., Traoré, A. S., Barro, N. (2015). Serotyping and antibiotic resistance of enteropathogenic Escherichia coli and E. coli $\mathrm{O} 157$ isolated from diarrheal children in rural area of Burkina Faso. African Journal of Microbiology Research. 9, 1053-1059.

European Food Safety Authority. (2012). EFSA guidelines. Rapport conjoint de l'EFSA et le Centre européen de prévention et de contrôle des Maladies (ECDC) sur la résistance aux antimicrobiens chez les bactéries zoonotiques affectant l'homme, l'animal et l'alimentation. $20 \mathrm{p}$. http://www.efsa.europa.eu/de/efsajournal/ consulted 22/12/2012 at 4h 58 AM.

Fadi, E. E., Rahal, E. A., Sleiman, F. T., Abdelnoor, A. M. (2012). Identification of Virulence Genes among Antibacterial-Resistant Escherichia coli isolated from Poultry. Advenced Studies In Biology. 8, 385-396.

Gassama-Sow, A., Aidara, A., Chainier, D., Denis, F., Ploy, M. C. (2004) Integron-associated antimicrobiotic resistance in enteroaggregative and enteroinvasive Escherichia coli. Microbial Drug Resistance 10, 27-29.

Igbeneghu, O. A., Lamikanra, A. (2014). Multiple-Resistant Commensal Escherichia Coli from Nigerian Children: Potential Opportunistic Pathogens. Tropical Journal of Pharmaceutical Research. 13, 423-428.

http://dx.doi.org/1O.4314/TJPR.V13i3.17

Ilboudo, A. J., Savadogo, A., Barro, N., Seydi, M., Traore, A. S. (2010). Qualité Microbiologique de La Viande Utilisée en Restauration Collective: Cas des Restaurants Universitaires de Ouagadougou, Burkina Faso. Revue de Microbiologie. Industrielle Sanitaire et Environnementale. 4, 99-113.

International Standard Organization. (1991). ISO 4832. MicrobiologieDirectives générales pour le dénombrement des coliformes-Méthode par comptage des colonies. AFNOR. 5p.

Isibor, J. O., Ekundayo, A. O., Ohenhen, R. E., Orhue, P. O. (2013). Escherichia coli O157:H7- Prevalence and Risk Factors of Infection in Edo State, Nigeria. American Journal of Research. 1, 35-49.

Kagambèga, A., Martikainen, O., Lienemann, T., Siitonen, A., Traoré, AS., Barro, N., Haukka, K. (2012). Diarrheagenic Escherichia coli detected by 16plex PCR in raw meat and beef intestines sold at local markets in Ouagadougou, Burkina Faso. International Journal of Food Microbiology. 153, 154-158.

Kotloff, K. L., Nataro, J. P., Blackwelder, W., Nasrin, D., Farag, T. (2013) Burden and aetiology of diarrhoeal disease in infants and young children in developing countries: a prospective, case-control study. Global Enteric Multicentre Study: 382, 209-222.

Mori, L., Perales, R., Rodríguez, J., Shiva, C., Koga, Y., Choquehuanca1, G., Palacios, C. (2014). Molecular Identification of Shiga-Toxin Producing and Enteropathogenic Escherichia coli (STEC and EPEC) in Diarrheic and Healthy Young Alpacas. Advances in Microbiology. 4, 360-364.

http://dx.doi.org/10.4236/aim.2014.47043

Moyo, S. J., Maselle, S. Y., Matee, M. I., Langeland, N., Mylvaganam, H. (2007). Identification of diarrheagenic Escherichia coli isolated from infants and children in Dar es Salaam, Tanzania. BMC Infectious Diseases. 7, 1-7.

Müller, D., Greune, L., Heusipp, G., Karch, H., Fruth, A., Tschäpe, H., Schmidt, H. A. (2007). Identification of unconventional intestinal pathogenic Escherichia coli isolates expressing intermediate virulence factor profiles by using a novel 
single-stepmultiplex PCR. Applied and Environmental Microbiology. 73, 33803390 .

Nataro, J. P., Kaper, J. B. (1998). Diarrheagenic Escherichia coli. Clinical Microbiology Reviews. 11, 142-201.

Neter, E., Westphal, O., Luderitz, O., Gino, R. M., Gorzynski, E. A. (1955).

Demonstration of antibodies against enteropathogenic Escherichia coli in sera of children of various ages. Pediatrics. 16, 801-808.

Organisation Mondiale de la Santé. (2015). OMS guidelines. Journée mondiale de la Santé 2015, la sécurité sanitaire des aliments vos aliments sont-ils vraiment sûrs ? De la ferme à l'assiette, vous avez tous un rôle à jouer. Guide de sensibilisation. 12p. http://www.who.int/foodsafety/fr/consulted 28/08/2015. at $11 \mathrm{~h} 15 \mathrm{mn}$ PM.

Paton, J. C., Paton, A. W. (1998). Pathogenesis and diagnosis of Shiga toxinproducing Escherichia coli infections. Clinical Microbiology Reviews. 11, 450479.

Rahimi, E., Nayebpour, F. (2012). Antimicrobial resistance of Escherichia coli O157:H7/NM isolated from feces of ruminant animals in Iran. Journal of Cell and Animal Biology. 6, 104-108.

http://dx.doi.org/10.5897/JCAB11.082

Saeed, A., Abd, H., Sandstrom, G. (2015). Microbial aetiology of acute diarrhoea in children under five years of age in Khartoum. Sudan Journal of Medical Microbiology. 64, 432-437.

http://dx.doi.org/10.1099/jmm.0.000043

Sarker, N., Sharmin, I., Mehedi, H., Farzana, K., Aftab, U. Md., Rashed, N. (2013). Use of Multiplex PCR Assay for Detection of Diarrheagenic Escherichia coli in Street Vended Food Items. American Journal of Life Sciences. 1, 267-272. http://dx.doi.org/10.11648/j.ajls.20130106.15

Timbiné, L. G., Sambe-BA, B., Wane, A. A., Fall, N. K., Abdou, M., Barro, N., Sangaré, L., Bougoudogo, F., Gassama-Sow, A. (2013). Sensibilité aux antibiotiques des souches de bactéries entéropathogènes isolées en Afrique de l'Ouest (Burkina Faso, Mali, Sénégal). Dakar Medical Journal. 58, 80-88.

Vidal, M, Kruger, E, Durán, C, Lagos, R, Levine, M, Prado, V, Toro, C, Vidal, R. (2005). Single multiplex PCR assay to identify associated with enteric infections. Journal of Clinical Microbiology. 43:5362-5365. 